\title{
EFFECTIVENESS OF READING ALOUD STRATEGIES ON LOW PROFICIENCY PAKISTANI COLLEGE LEVEL FEMALE STUDENTS OF ENGLISH DEPARTMENT FROM HUMANITIES GROUP AT HIGHER SECONDARY SYSTEM: A TEACHERS' PERCEPTION
}

\author{
Muhammad Khalid Mehmood Sajid \\ Ph.D. Scholar, Centre for Modern Languages, Universiti Malaysia Pahang, Malaysia \\ English Language Lecturer, College of Applied Medical Sciences, \\ King Saud bin Abdulaziz University for Health Sciences, Al Ahsa, Saudi Arabia \\ Email: interstudies2000@gmail.com \\ Dr. Hafizoah Kassim \\ Associate Professor \\ Deputy Dean Research \& Postgraduate Studies \\ Centre for Modern Languages, Universiti Malaysia Pahang, Malaysia \\ Dr. Abdullah Al Fraidan \\ Associate Professor, \\ English Language Department, \\ College of Arts, King Faisal University, Alhasa, Saudi Arabia \\ Dr. Ghassan Adnan Hasan \\ Assistant Professor, \\ English Language Centre, \\ Preparatory Year Deanship, King Faisal University, Alhasa, Saudi Arabia
}

Dr. Zafar Iqbal

Associate Professor

College of Applied Medical Sciences,

King Saud bin Abdulaziz University for Health Sciences, Al Ahsa, Saudi Arabia

Dr. Khaled Aljarrah

Associate Professor

College of Applied Medical Sciences,

King Saud bin Abdulaziz University for Health Sciences,

Al Ahsa, Saudi Arabia

Dr. Nawaf Al Anazi

Assistant Professor

Dean, College of Applied Medical Sciences,

King Saud bin Abdulaziz University for Health Sciences, Al Ahsa, Saudi Arabia

Abstract:

Reading is an important part of learning. No one can deny its importance. The importance of reading aloud strategies has increased. Reading aloud strategies are very important, especially for low proficiency students and for those who use the 
English language as a second language. It is vital for low proficiency students at the national and international levels. This study examines the effectiveness of the read-aloud strategies on low proficiency students at the secondary school level in Multan city. The study was conducted at the higher secondary school of Multan city in Pakistan; data were collected from students of the first year through a questionnaire, and pre-test post-test instruments were also used. The study is based on an experimental research design, and the target sample was 20 students of humanities group and five teachers from the English department. The study found that the reading aloud strategies help low proficiency students at the college level in Pakistan.

Keywords: Reading aloud strategy, low proficiency students

\section{INTRODUCTION}

The strategy is a long-term direction which is used to achieve any goal and a pattern in a stream of decision (Mintzberg, 2007). Reading is a significant learning source, and the reading aloud strategies (RAS) are getting a prominent place nowadays. RAS are a way of demonstration and build confidence. RAS help enhance vocabulary and confidence in students and motivates students for learning (Dörnyei, 2001). These strategies help in simplifying a challenging text and make it understandable. Read aloud improves the foundation for literacy development and reading successfully (Neuman, Copple, \& Bredekamp, 2000). Pakistan is a developing country where English is getting a place as an international language, while Urdu is the national language (Iqbal \& Ahmad, 2010). According to Rasheed, Saleem, Bukhsh, and Rasul (2011), Pakistan's national language and English as an international language has no similarity and both are different. It is not easy for people to learn and understand English. Students cannot read English fluently, and even in some cases, it is hard for them to write a simple application in the English language. Students have cramming habit, and the purpose of reading is only to pass an exam. They have low tense structure, and they are unfamiliar with different reading strategies. They even do not know how to read in chunks; that is why most students have poor reading ability in English because they are unfamiliar with basic reading strategies. Poor reading is at an introductory level in Pakistan; read aloud strategy is followed, while at the college level, the silent reading strategy is used. Read aloud strategies help students at the school level and a higher level, mostly when English is used as a second language. Effective reading is essential, and in Pakistan, RAS are used widely in schools. Still, the silent reading method is difficult for students at the college level, primarily from Urdu medium schools. Students have a problem with vocabulary, pronunciation, word decoding, and comprehension. RAS are beneficial for students who are using English as a foreign language, and this technique is positive even at the college level. RAS help students build self-confidence and pronounce difficult words (Ninsuwan, 2015). RAS are helpful in foreign language teaching. The impact of the RAS is positive among students and on their academic careers. These strategies helped improve oral reading, pronounce difficult words, and build confidence in students. More reading aloud practice would be helpful in more self-confidence of communication (Huang, 2010). Read aloud strategies help students at the national level and at the international level to improve students' learning with low proficiency. The present study attempts to check the effectiveness of the RAS at the secondary school level because past research was conducted at the college level. In contrast, secondary school level was ignored in Pakistan. In past research, text reading instruments were not used by researchers. The present study is a novel research, and its purpose is to know the effectiveness of RAS on low proficiency Pakistani students of humanities group.

\section{BACKGROUND}

\subsection{Review of Literature}

This section will discuss the reviews of various related researches based on the reading aloud strategies. Ninsuwan (2015) examined the effectiveness of Teaching English by using the reading aloud techniques for EFL beginners. For this purpose, a sample size of twenty students was selected to check their capability in understanding English. The study aimed to test the difference among different students of the first year that how much they understand English, check effectiveness of reading aloud strategy, aware students with other English skills, and suggest an effective technique for EFL beginners. Two techniques, pre-test, and posttest were employed to analyze results. Findings show that the RAS is beneficial for students who are using English as a foreign language. Results for this technique are positive even at the college level. RAS was helping students in building self-confidence and 
pronouncing difficult words. Overall RAS had significantly impacted students' learning and academic career at the college level. Huang (2010) explained about RAS in foreign language teaching. Studies show that the RAS' impact was positive among students and in their academic careers. RAS helped improve oral reading, pronounce difficult words, and build confidence in students. More reading aloud practice would be useful for more self-confidence in communication. Dhaif (1990) explained about reading aloud English comprehension at the University of Bahrain. Studies show that students were divided into two groups, provided with comprehension paragraphs. Findings show that a group of reading aloud techniques had significantly higher results than the silent reading technique. Generally, RAS were found useful for EFL and ESL readers even at a basic and high level. Muhammad (2013) highlighted second language reading instruction in Pakistan. Studies show that in Pakistan, a traditional medium of teaching was used. A mixed-method research design was used. The targeted population was 71 English teachers from six public universities of Pakistan. A questionnairebased on a five-point Likert scale was provided to collect information. The study results show that most teachers know the direction of the educational goals they should achieve. Classroom practice for students was found poor, and no teacher follows the classroom practice. The used strategies were reading aloud, asking students to read text orally and then asking questions, selective evaluation of the text, and other essential reading skills that they could use were added in the classroom to make reading skills effective. There was found a wider gap between what the teachers think and what they do in the classroom. Overall RAS were found helpful. Santos Varon, Romaña Acuña, and Zapata Muñoz (2012) highlighted Reading aloud as an instructional strategies to develop Elementary School Children's skills in a foreign language in a public school in Colombia. Different methods were employed to collect the data, including observation, field diaries, and interviews. The findings show that the RAS effectively build motivation, enhances vocabulary learning, and builds confidence. It was also helpful in building interest in learning a foreign language. It was effective not only in keeping engage to the reader but also the audience. Kazi and Iqbal (2011) explained the use of Language Learning Strategies (LLS) by students at higher secondary level in Pakistan. Targeted students were from science, commerce, and humanities disciplines from levels six, seven, and students from higher secondary public and private colleges were also added to collect information. The instruments used for this study were Individual Background Questionnaire (IBQ) and The Language Learning Strategies Inventory (LLSI). The study found that metacognitive studies were preferred among students. It was found that students had focused on those words and paraphrase what they already know and try to know about the delivered lecture's idea. In this way, they depend upon selective conversation. Their listening skills were also found poor as they rely on guessing the idea, they did not know what was going on. Overall, students' proficiency in the foreign language and reading was found poor in Pakistan. Rasheed et al. (2011) discussed identification of reading difficulties in the subject of English at secondary level federal school in Pakistan's Punjab district. From seven schools of federal, the selected respondents were 280. A survey was conducted, and a five-point Likert scale questionnaire was provided to collect the data. Findings show that most respondents were found poor in vocabulary use, pronouncing a foreign language, and abbreviation identification. The reason behind poor reading skills was poor interest of students towards learning and reading. Silent reading was found difficult for students, while the RAS were considered easy. It was suggested that reading skills could be improved by frequent reading English newspapers and by reading different reading books. Park and Choo, Eng, and Ahmad (2011) explained about Improvement in English after a 15 week read aloud program in third grade EFL students in Korea. The targeted students were from level three. Students were provided with oral, written tests and questionnaire to get information. Study show that students who were selected for this purpose had shown positive response. They had more ability of listening and reading after the reading aloud program as compared to their other fellows. RAS were found helpful for students. Chen and Chen (2015) explained about the use of EFL reading strategies among high school students in Taiwan. 1259 students were selected from 34 schools in Taiwan by using the Survey of Reading Strategies (SORS) along with global reading strategies and problem-solving strategies. Study shown that female students had more awareness and interest for reading strategies as compared to male. Globally reading strategies were followed in schools 
and it was suggested that better results could be achieved if students would ensure their understandings of these strategies. (Wang, 2015) explained about effect of metacognitive strategy training on Chinese EFL learners' reading competence in China. Study shows that reading is an important learning strategy while metacognitive strategies helped learn English and improve the student's learning capabilities. A mixed methodology was used to collect information. A study discovered that metacognitive should use applying strategies to make reading strategies efficient and helpful and enhance their autonomous learning ability. Individual differences were also found useful to increase student's interest towards learning outcomes. Hassan (2014) highlighted the pronunciation problems among English language students at Sudan University of Science and Technology. The study attempted to find out pronunciation problems related to English as a second language, while the actual spoken language was Arabic. A mixed methodology was used for collecting data, including observation method, questionnaire, and recordings. Study shows that student had problems with English sound pronunciation and spellings were found the problem for Sudanese students. Steinagel (2005) pointed out the effects of reading \& reading strategies' training on lower proficiency level second language learning in Provo, Utah. Two hundred and fourteen native English speakers were selected for this purpose to know the effect of the RAS on English as second language. The experimental design was used to that effect. It was found that RAS were helping in improving the learning ability of students and it was responsible for enhancing confidence among them and it was also found that training for learning second language and its strategies was helpful in learning a second language. Choo et al. (2011) stated about the effects of reciprocal teaching strategies on reading comprehension in Malaysia. Study was conducted on sixth form students among them 68 students were selected who had incredibly low proficiency of English. Study had used qualitative and quantitative data with a quasi-experimental research design, which was used for this purpose. The mixed-method technique was used, including pre-test, post-test, and open-ended questions. The study found that reciprocal teaching was considered effective in improving students' reading comprehension and learning abilities. The widespread use of reciprocal strategies was found helpful in reading comprehension in Malaysia.

Ozek and Civelek (2006) examined the Study on the use of cognitive reading strategies by ELT students in Turkey. The study was conducted on first year and fourth-year students of the Dicle University of Turkey. The method used for this purpose was the self-report questionnaire and Think-Aloud Protocol (TAP) with reading strategies, including pre-reading and post-reading. The study found that students mostly use strategies related to the title of the text content. While reading, they were concentrating on use of dictionary and guessing strategy while for post reading their interest was poor. Study concluded that use of cognitive reading strategies was helpful for students in their learning and reading. Ball-Erickson (2012) explained effective reading comprehension strategies for students at elementary education level conducted for autism spectrum disorders in students. The study found that reading comprehension was necessary for learning, and teachers should use effective strategies for the reading comprehension of those students who had problems with ASD during learning. It was suggested that they should opt for a balanced approach to make their teaching skills helpful for weak students. Teevno (2011) highlighted the challenges in teaching and learning English at secondary level class $\mathrm{X}$ in district Naushahro Feroze Sindh Pakistan. Sample size, including 70 students, 11 teachers, and 6 English expertise were selected for this study. Study shown that there were many factors including no training of English course, use of grammar translation method, provision of English novels and books in libraries were not sufficient. Teachers had no time management skills and they were unable to face the challenges related to English language. Teachers had EFL skills and they had focus on RAS.

After an extensive review of different studies which were presented in different periods, it could reveal that various studies reveal a mixed pattern of findings such as Kazi and Iqbal (2011) and Rasheed et al. (2011) found that English as a second language was difficult for students at the college level in Pakistan. Whereas Ninsuwan (2015), Steinagel (2005), Haung (2010), Dhaif (1990) and Muhammad (2013) found that RAS were helpful for students at the college level. RAS were useful for those students who were using English as a second language, as Dhaif (1990) pointed out that RAS 
were better than the silent reading strategies (SRS). Overall, previous studies had shown that the RAS were helpful for low proficiency students. The present study attempts to check the RAS' effectiveness on low-level students in a Pakistani government secondary school.

\section{PROBLEM STATEMENT:}

Reading is essential in the learning process. In Pakistan, the English language is used as a foreign language. People feel difficulty in understanding and speaking the English language. In schools and colleges, the English language is taught as a compulsory subject. Students, mostly those who belong to rural areas or who do not have a robust English grammar base, cannot understand the lecture. They do not have enough listening and reading skills to read challenging text material in English. In most of the schools, teachers follow the SRS. In that case, low proficiency students unable to perform well, while these students could show good performance with the RAS. RAS help students who were taught with these strategies in their early schooling, while with SRS, they cannot express their ideas and skills for the English language.

\section{RESEARCH QUESTIONS:}

- To check the effectiveness of reading aloud strategies

- To check the effectiveness of reading aloud strategies on low proficiency of students

- Role of read-aloud strategies in text reading

\section{HYPOTHESIS:}

- Read aloud strategies are effective for low proficiency students

\section{MATERIAL AND METHODS}

\subsection{Data collection:}

For the recent study, data was collected from the higher secondary school of Multan city. Students were selected from a higher secondary school, Shuhda-e-APS (Memorial) Chah Bohar Wala, Multan. They had four groups at the college level, including ICS, Humanities, Pre-engineering, and Pre-medical. Data was collected from the humanities group of the first year. A pre- and posttest was used for the experimental study and a questionnaire technique was used to collect data, which was based on MCQ's for a survey.

\subsection{Sample size:}

\section{FINDINGS}

In table 1, students' response to pre-test and the post-test instrument was entirely different. Respondent 8 got $10 \%$ marks in the pre-test instrument, while in the post-test they got $90 \%$ marks. In pre-test, respondent 1, 2, 9 and 11 obtained $20 \%$ marks while in post-test they got $100 \%, 70 \%$, $60 \%$ and $50 \%$, respectively. Respondent 4, 6, 10, 16 and 20 got $30 \%$ in pre-test instrument, while in posttest they had got $80 \%, 70 \%, 60 \%$, and $70 \%$ and $60 \%$ marks, respectively. Respondent 5,7,13, 17 and 19 had got $40 \%$ marks in pre-test instrument while in post-test they had got $100 \%, 70 \%, 70 \%, 100 \%$ and $80 \%$ respectively. Respondents 12 and 18 got $50 \%$ 
marks in the pre-test instrument, while in the posttest, they got $80 \%$ and $60 \%$, respectively. Respondents 3 and 15 got $60 \%$ marks in the pre-test instrument, while in the post-test, they got $70 \%$ and $60 \%$, respectively. Respondent 14 got zero marks in the pre-test instrument, while the post-test instrument got $80 \%$ marks. Results show that student's performance was better for post-test results as compared to pre-test results. They had performed well with the RAS as compared to the SRS.

The pre-test instrument was based on chapter 1 named "Button, button" of English textbook for which teachers had used silent reading strategies while the post-test instrument was developed for chapter 4 "Thank you, Ma'am," of English text. Chapter 4 was taught during experimental research design using RAS. In the first two days, students were assessed and then provided with a pre-test instrument. Students' response was positive for the RAS, and students were taught by using different reading techniques. Initially, they explained the topic, and they were presented with difficult words for each line. Moreover, they were asked to read aloud a given paragraph of the English textbook one by one from the selected 20 respondents. The RAS were helpful for low proficiency learners, while these students performed poorly with silent reading strategies.
In table 2, Pretest and post-test instrument results were compared using a paired t-test with the help of mean value difference of pre-test and post-test was 4.10000, for standard deviation it was 2.31471,

\begin{tabular}{|c|c|c|c|}
\hline \multicolumn{2}{|c|}{ Pre-test results } & \multicolumn{2}{c|}{ Post test results } \\
\hline Respondents & Obtained Percentage & Respondents & Obtained Percentage \\
\hline $\mathbf{1}$ & $20 \%$ & $\mathbf{1}$ & $100 \%$ \\
\hline $\mathbf{2}$ & $20 \%$ & $\mathbf{2}$ & $70 \%$ \\
\hline $\mathbf{3}$ & $60 \%$ & $\mathbf{3}$ & $70 \%$ \\
\hline $\mathbf{4}$ & $30 \%$ & $\mathbf{4}$ & $100 \%$ \\
\hline $\mathbf{6}$ & $40 \%$ & $\mathbf{5}$ & $70 \%$ \\
\hline $\mathbf{7}$ & $30 \%$ & $\mathbf{6}$ & $70 \%$ \\
\hline $\mathbf{8}$ & $40 \%$ & $\mathbf{7}$ & $90 \%$ \\
\hline $\mathbf{9}$ & $10 \%$ & $\mathbf{8}$ & $60 \%$ \\
\hline $\mathbf{1 0}$ & $20 \%$ & $\mathbf{9}$ & $60 \%$ \\
\hline $\mathbf{1 1}$ & $30 \%$ & $\mathbf{1 0}$ & $50 \%$ \\
\hline $\mathbf{1 2}$ & $20 \%$ & $\mathbf{1 1}$ & $80 \%$ \\
\hline $\mathbf{1 3}$ & $50 \%$ & $\mathbf{1 2}$ & $70 \%$ \\
\hline $\mathbf{1 4}$ & $40 \%$ & $\mathbf{1 3}$ & $80 \%$ \\
\hline $\mathbf{1 5}$ & $0 \%$ & $\mathbf{1 4}$ & $60 \%$ \\
\hline $\mathbf{1 6}$ & $60 \%$ & $\mathbf{1 5}$ & $70 \%$ \\
\hline $\mathbf{1 7}$ & $30 \%$ & $\mathbf{1 6}$ & $100 \%$ \\
\hline $\mathbf{1 8}$ & $40 \%$ & $\mathbf{1 7}$ & $60 \%$ \\
\hline $\mathbf{1 9}$ & $50 \%$ & $\mathbf{1 8}$ & $80 \%$ \\
\hline $\mathbf{2 0}$ & $40 \%$ & $\mathbf{1 9}$ & $\mathbf{2 0}$ \\
\hline
\end{tabular}

SPSS. Statistical analysis shows that the Mean value for pre-test marks was 3.3000, while post-test marks had a mean value of 7.4000. The standard deviation for the pre-test instrument was 1.55935, while the post-test standard deviation was 1.46539. The standard error mean was .34868 for pre-test, and for post-test, it was .32767. Table 2 shows that the paired samples test difference indicates that the standard error mean value was .51759 and $t=-7.921$. Statistical analysis results show that students' performance was better for the RAS at the college level than with the silent reading strategies. The RAS were helpful for passive learners because they performed better when they were taught with silent reading strategies. With the SRS, they found English text reading exceedingly difficult for them.

Table 1 Comparison of Pre-test and Post-test results in Percentages 


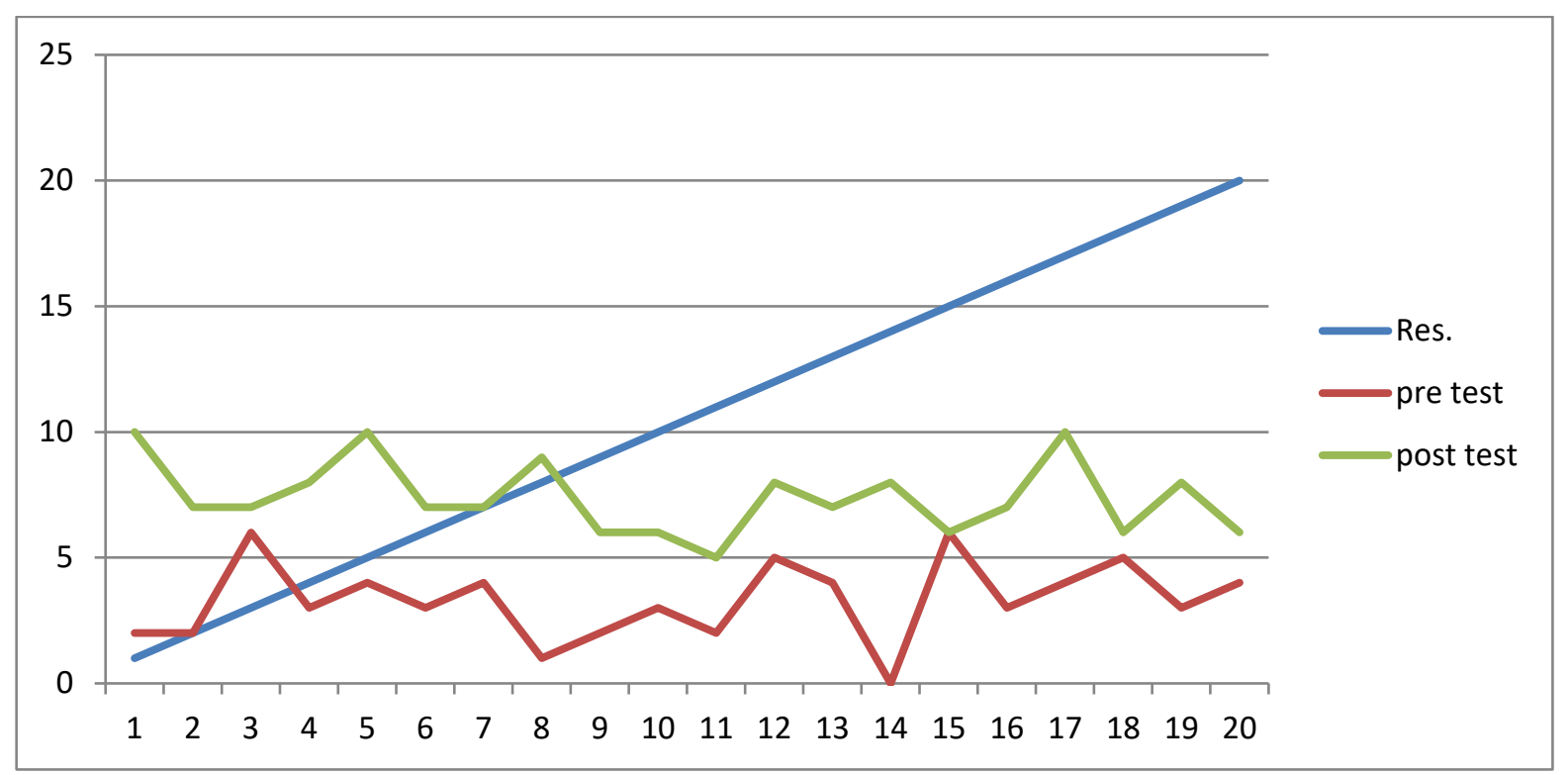

Fig. 4.1 Trend pattern of Pre-test post-test instrument

The pre-test post-test instrument trend pattern can be observed with the help of a line chart. It can be analyzed that the post-test trend was high compared to the pre-test instrument, which shows that students' performance was increased in the post-test instrument, so we can conclude that RAS were effective for low proficiency students at the school level.

Table 2 Statistical Analysis of Pre-test Post-test results with paired t-test using SPSS

Paired Samples Statistics

\begin{tabular}{|ll|r|r|r|r|}
\hline & \multicolumn{1}{|c|}{ Mean } & N & Std. Deviation & Std. Error Mean \\
\hline Pair 1 & pretest marks & 3.3000 & 20 & 1.55935 & .34868 \\
& posttest mark & 7.4000 & 20 & 1.46539 & .32767 \\
\hline
\end{tabular}

Paired Samples Test

\begin{tabular}{|c|c|c|c|c|c|c|c|c|}
\hline & \multicolumn{5}{|c|}{ Paired Differences } & \multirow[b]{3}{*}{$\mathbf{t}$} & \multirow[b]{3}{*}{ df } & \multirow{3}{*}{$\begin{array}{l}\text { Sig. (2- } \\
\text { tailed) }\end{array}$} \\
\hline & \multirow[b]{2}{*}{ Mean } & \multirow{2}{*}{$\begin{array}{c}\text { Std. } \\
\text { Deviation }\end{array}$} & \multirow{2}{*}{$\begin{array}{l}\text { Std. } \\
\text { Error } \\
\text { Mean }\end{array}$} & \multicolumn{2}{|c|}{$\begin{array}{l}95 \% \text { Confidence } \\
\text { Interval of the } \\
\text { Difference }\end{array}$} & & & \\
\hline & & & & Lower & Upper & & & \\
\hline $\begin{array}{l}\text { pretest marks } \\
\text { - } \\
\text { posttest mark }\end{array}$ & -4.10000 & 2.31471 & .51759 & -5.18332 & -3.01668 & -7.921 & 19 & .000 \\
\hline
\end{tabular}

At the end of the research, students were provided with an instrument to know their opinion about the RAS. The instrument was based on ten questions with a five-point Likert scale. Table 3 shows students' responses to RAS, which was asked at the end of the experimental research design. RAS helped understand difficult words, and the mean value for it was 1.1 , among which $85 \%$ response was vital to agree, and $15 \%$ agreed for this. The mean value for the RAS was building confidence in student and the mean value was 1.2. RAS helped in understanding the idea of the text. It was helpful in the evaluation, understanding teachers lecture, and better understood as compared to the SRS, all 
questions having a 1.3 mean value. The mean value was 1.4 for the RAS, which was causing in summarizing the whole text and improving students' pronunciation. The highest mean value was 1.5 , as the RAS helped students express their idea about any given text means; by reading text with the RAS, they could evaluate what comes next and about the text's basic concept RAS were most effective in expressing the whole idea about text and improving students' pronunciation, while it was also helpful in summarizing the difficult text reading. Students' performance with the RAS were efficient and significant as compared to the SRS. In Pakistan, students had their background for a foreign language with a RAS. At the same time, they were not comfortable with SRS followed by teachers at the college level. That was why students had poor English reading skills and could not understand what the teachers were teaching them at the college level.

Table 3: Instrument provided to students to know their opinion about RAS

\begin{tabular}{|c|c|c|c|c|c|c|c|}
\hline Q.no & \multirow[t]{2}{*}{ statement } & SA & $\mathbf{A}$ & $\mathbf{N}$ & DA & SDA & MEAN \\
\hline & & $\%$ & $\%$ & $\%$ & $\%$ & $\%$ & \\
\hline 1 & Read aloud strategy makes me feel more confidence & 75 & 25 & 0 & 0 & 0 & 1.2 \\
\hline 2 & Read aloud is helpful in improving my pronunciation & 65 & 30 & 5 & 0 & 0 & 1.4 \\
\hline 3 & $\begin{array}{l}\text { This strategy is helping me in understanding the idea of } \\
\text { the text }\end{array}$ & 70 & 25 & 5 & 0 & 0 & 1.3 \\
\hline 4 & It is helpful in expressing my idea about text & 55 & 40 & 5 & 0 & 0 & 1.5 \\
\hline 5 & When I read aloud, I can evaluate what I have read & 65 & 35 & 0 & 0 & 0 & 1.3 \\
\hline 6 & It helps me in summarize the entire text & 65 & 30 & 5 & 0 & 0 & 1.4 \\
\hline 7 & When I read aloud,I can predict about next idea & 80 & 15 & 5 & 0 & 0 & 1.2 \\
\hline 8 & 8.Read aloud is helpful for understanding difficult text & 85 & 15 & 0 & 0 & 0 & 1.1 \\
\hline 9 & I can understand when teacher read aloud & 75 & 20 & 5 & 0 & 0 & 1.3 \\
\hline 10 & $\begin{array}{l}\text { I feel comfortable with reading aloud as compare to } \\
\text { silent reading }\end{array}$ & 70 & 0 & 0 & 0 & 0 & 1.3 \\
\hline
\end{tabular}

At the end of the research, an instrument was provided to five English department teachers to know their opinion about the RAS. Table 4 shows the results for RAS based on teachers' view from the English department. Teachers initially give students feedback about the text, for which $80 \%$ strongly agreed, and $20 \%$ agreed, and the mean value for this response was 1.2. Teachers who preferred the RAS were $80 \%$ who strongly agreed while $20 \%$ agreed, and the Mean value was 1.2. Teachers who used the recapitulation method and who provide extra help to students also have the same percentage and mean value. The highest mean value indicates that the RAS kept students active, which was 1.6.

Table 4: Instrument provided to teachers to know their opinion about RAS

\begin{tabular}{|c|l|c|c|c|c|c|c|}
\hline Q.no & Statement & SA & A & N & DA & SDA & \multirow{2}{*}{ MEAN } \\
\cline { 1 - 4 } & & $\%$ & $\mathbf{\%}$ & $\mathbf{\%}$ & $\mathbf{\%}$ & $\mathbf{\%}$ & \\
\hline $\mathbf{1}$ & I initially give students feedback of the topic & 80 & 20 & 0 & 0 & 0 & 1.2 \\
\hline $\mathbf{2}$ & I prefer reading aloud strategies & 80 & 20 & 0 & 0 & 0 & 1.2 \\
\hline
\end{tabular}




\begin{tabular}{|c|l|c|c|c|c|c|c|}
\hline $\mathbf{3}$ & Read aloud strategies keep students active & 40 & 60 & 0 & 0 & 0 & 1.6 \\
\hline $\mathbf{4}$ & I use recapitulation method at the end of lecture & 80 & 20 & 0 & 0 & 0 & 1.2 \\
\hline $\mathbf{5}$ & I provide extra help to students if they feel difficulty & 80 & 20 & 0 & 0 & 0 & 1.2 \\
\hline
\end{tabular}

5

\section{. DISCUSSION}

From the results of the pre-test and posttest instruments, it could conclude that post-test results were more significant than the pre-test instrument. The post-test instrument percentage was higher than the pre-test instrument for RAS as compared to the SRS. Reading instrument was developed from the English textbook of the first year. Chapter one was used for the pre-test instrument, while chapter four was used for the posttest instrument. Teachers were using the SRS for text reading. Students reading proficiency was low, and they were feeling difficulty in text reading because English as an international language was not understandable for them, especially for low proficiency learners. Students were taught with RAS under experimental research design, and they were provided with a questionnaire, so they had shown significant results. Convenience sampling was used for the present study because it is better for experimental research design (Kendall, 2003).

Reading skills could improve by listening to others and reading aloud helps connect a relation between printed words of text and their meaning (Al-Mansour, 2011). Teachers believed that RAS helped understand the problematic text and build confidence among students. It was useful in evaluating the text idea and in understanding the teachers' lecture. It enhances the base for literacy development and keeps busy not only listeners but also the readers. Students prefer higher languages as compared to low-level reading. The RAS helped students increase their vocabulary level and understand the language pattern of different languages. It was helping in improving the pronunciation and guessing power of students about a given text. Teachers had an opinion that RAS were beneficial in keeping students active. Teachers prefer RAS, but they could not implement that strategies at the college level (Tofade, 2013). They also used the recapitulation method and gave extra time to those students who had difficulty reading English.

\section{SUGGESTIONS}

Reading is an important task of learning. As English is an international language in Pakistan, it is indispensable to easily read it and understand it. Students must know about the core competencies of reading. Teachers should give awareness to them with basic skills of reading. Teachers should use different reading skills so that students do not rely only on one reading habit; they must be familiar with multiple strategies because different reading strategies are being used at various levels. Students should be taught about basics and easy ways of reading, e.g., reading in chunks, word by word reading, and read aloud at the basic and initial level; it would help them not only in reading in fluency but also in speaking. Teachers should follow RAS, especially in rural areas where students are not provided with audio and video aids facilities and other facilities of improving English reading, e.g., Tape recorder role play, etc. In such cases, if students read aloud, they can read aloud to improve their reading fluency and understanding of the English language. Rote learning should be discouraged in students because it is responsible for poor reading and learning habits, and with rote learning, students merely learn text material. At the same time, they have no understanding of that text. It is the best way to share their feelings, ideas, and knowledge.

Activities should be organized in the classroom to develop reading habits among students. It is helpful in a high-level understanding of a text. Teachers should offer model reading and then gave activities to students to perform. If students get an opportunity to read mini text reading daily, they could improve their reading fluency. Read aloud strategies can make the classroom learning environment more effective by keeping students busy and active because it engaged both speaker and listener simultaneously. Before reading a text, teachers should assign students one day before so that they could practice, for it would not be effective to assign them reading any text when they would not ready or had not seen the text before. Reading activities should be purposeful so that learning 
objectives could fulfill and students improve their reading skills. Students' interest could develop by providing them any familiar topic or that kind of text for which they had interest and curiosity. Teachers should discuss with students and then point them out for their mistakes about reading. Clarify student's concepts about reading so that they may know what they are reading, and they should monitor appropriately. Reading listening activities should organize so that students could improve their listening and reading skills, and in this way, both listener and speaker remain busy and active.

\section{CONCLUSION}

RAS helped improve comprehension skills in students. They could read the text material of any level, and in this way, they would not find any difficulty and can easily handle that condition. Reading aloud is vital for students learning and verbal expressions. If they would enable to pronounce difficult words, they could be able to read text early and fluently.

With patience and in a clear voice, read slowly could improve reading aloud capacity and confidence building. RAS could improve reading and listening ability of students which was proved by post-test results as students had performed best in post-test as compared to pre-test instrument which was provided to them

RAS was not only helpful for the local language but also for foreign language in Pakistan. Read aloud approach was improving confidence among students. It was helping in enhancing the vocabulary and pronunciation of students at every stage. RAS was remarkably effective for poor readers. RAS helped improve students' listening skills, understand teachers' lectures, and guess the power of students about a text. Teachers preferred RAS because these strategies were particularly useful in keeping students busy and active. RAS were helpful in memorization and in capturing the idea of the whole text. In Pakistan, were also useful for low proficiency students who could be shown with pre and post-test instrument results. These strategies were also helping students not only at the school level but also at the college level.

RAS were playing an influential role for students. In the college, students who belong to private schools, they understood the English language quickly. Still, students had poor English reading skills and poor pronunciation for the English language from rural areas. At the college level, students feel English, which was a foreign language in Pakistan complicated and challenging. The primary reason was students' poor base developed at the initial level of school. That is why students at the college level were also felt difficulty while reading, listening, speaking, or writing English. Students were taught with RAS at the school level, while at college level teachers were using SRS that was difficult for students.

Experimental research design study showed that students' performance was effective with the RAS, and it could be concluded that these strategies were helping students at both school and college level in Pakistan. Overall, it could be shown that the RAS played a useful role in low proficiency and high proficiency students, and they were more effective than silent reading at school and college level in Pakistan.

\section{References}

1. Ball-Erickson, M. (2012). Effective reading comprehension strategies for students with autism spectrum disorders in the elementary general education classroom. Unpublished doctoral dissertation). North Michigan University, MI.

2. Chen, K. T.-C., \& Chen, S. C.-L. (2015). The use of EFL reading strategies among high school students in Taiwan. The Reading Matrix: An International Online Journal, 15(2), 156-166.

3. Choo, T. O. L., Eng, T. K., \& Ahmad, N. (2011). Effects of reciprocal teaching strategies on reading comprehension. Reading Matrix: An International Online Journal, 11(2).

4. Dhaif, H. (1990). Reading aloud for comprehension: A neglected teaching aid. Reading in a Foreign Language, 7(1), 457464.

5. Dörnyei, Z. (2001). Motivation strategies in the language classroom: Ernst Klett Sprachen.

6. Hassan, E. M. I. (2014). Pronunciation Problems: A Case Study of English Language Students at Sudan University of Science and Technology. English Language and Literature Studies, 4(4), 31.

7. Huang, L. (2010). Reading aloud in the foreign language teaching. Asian Social Science, 6(4), 148. 
8. Iqbal, M. J., \& Ahmad, M. (2010). Enhancing quality of education through elearning: the case study of Allama Iqbal Open University. Turkish Online Journal of Distance Education, 11(1).

9. Kazi, A. S., \& Iqbal, H. M. (2011). Use of Language Learning Strategies by Students at Higher Secondary Level in Pakistan. International Journal of Social Sciences and Education, 1(4), 557-574.

10. Mintzberg, H. (2007). Tracking strategies: Toward a general theory: Oxford University Press on Demand.

11. Muhammad, S. (2013). Second language reading instruction in Pakistan. ProcediaSocial and Behavioral Sciences, 70, 14031412.

12. Neuman, S. B., Copple, C., \& Bredekamp, S. (2000). Learning to read and write: Developmentally appropriate practices for young children: ERIC.

13. Ninsuwan, P. (2015). The Effectiveness of Teaching English by Using Reading Aloud Technique towards EFL Beginners. Procedia-Social and Behavioral Sciences, 197, 1835-1840.

14. Ozek, Y., \& Civelek, M. (2006). A study on the use of cognitive reading strategies by ELT students. The Asian EFL Journal, 14(1), 1-26.

15. Rasheed, S., Saleem, A., Bukhsh, Q., \& Rasul, S. (2011). Identification of Reading Difficulties in the Subject of English at Secondary Level: A Case Study of Federal Govt. Schools. International Journal of Social Sciences \& Education, 1(4).

16. Santos Varon, J., Romaña Acuña, C., \& Zapata Muñoz, A. (2012). Reading aloud as an instructional strategy to develop elementary school children's reading skills in a foreign language.

17. Steinagel, L. O. (2005). The Effects of Reading \& Reading Strategy Training on Lower Proficiency Level Second Language Learning.

18. Teevno, R. A. (2011). Challenges in teaching and learning of English at Secondary Level Class X. International Journal of Human Resource Studies, 1(2), 27.

19. Wang, X. (2015). Effect of Meta-cognitive Strategy Training on Chinese EFL Learners' Reading Competence. International Journal of English Linguistics, 5(1), 159.

\section{Instrument for Students}

\begin{tabular}{|c|c|c|c|c|c|}
\hline Statement & S. A & $\mathbf{A}$ & $\mathbf{N}$ & S. D & D.A \\
\hline 1.Read aloud strategy makes me feel more confidence & & & & & \\
\hline 2.Read aloud helps improve my pronunciation & & & & & \\
\hline $\begin{array}{l}\text { 3.This strategy is helping me in understanding the idea of the } \\
\text { text }\end{array}$ & & & & & \\
\hline 4.It helps express my idea about the text & & & & & \\
\hline 5. When I read aloud, I can evaluate what I have read & & & & & \\
\hline 6.It helps me summarize the entire text & & & & & \\
\hline 7.When I read aloud, I can predict about next idea & & & & & \\
\hline 8. Read aloud helps understand difficult text & & & & & \\
\hline 9.I can understand when the teacher read aloud & & & & & \\
\hline $\begin{array}{l}\text { 10. I feel comfortable with reading aloud as compare to silent } \\
\text { reading }\end{array}$ & & & & & \\
\hline
\end{tabular}




\section{Instrument for Teachers}

\begin{tabular}{|c|c|c|c|c|c|}
\hline Statement & S. A & $\mathbf{A}$ & $\mathbf{N}$ & D.A & $\mathbf{A}$ \\
\hline 1.I initially give students feedback on the topic & & & & & \\
\hline 2. I prefer to read aloud strategy & & & & & \\
\hline 3. Read aloud strategy keeps students active & & & & & \\
\hline 4. I use the recapitulation method at the end of the lecture & & & & & \\
\hline 5. I provide extra help to students if they feel difficulty & & & & & \\
\hline 6. I follow the translation method in improving their reading & & & & & \\
\hline 7. I explain to students about difficult words & & & & & \\
\hline $\begin{array}{l}\text { 8. students' performance is better in read-aloud strategy as } \\
\text { compared to silent reading }\end{array}$ & & & & & \\
\hline
\end{tabular}

